\title{
Commentary on "Electrophysiological Properties of in vitro Purkinje Cell Dendrites in Mammalian Cerebellar Slices. J Physiol 1980;305:197-213."
}

\author{
Rodolfo R. Llinás
}

Published online: 14 June 2012

(C) Springer Science+Business Media, LLC 2012

The paper being featured in this Cerebellar Classics, published in collaboration with Dr. M. Sugimori (this was the second of two back-to-back papers), represents the state of affairs of single-cell electrophysiology, in particular that related to Purkinje cells, at the beginning of the 1980s. Using cerebellar slices, rather than the usual in vivo recording methods of the time, several neuronal integrative principles, which had been hotly debated during the decades of the 1970s, were squarely addressed. The two main issues at the forefront were the following. First, do neurons and, in particular, Purkinje cells generate dendritic spikes? Second, are these spikes generated by inward sodium or calcium ionic flow?

This debate commenced with the original papers concerning dendritic spikes in the reptilian cerebellum (alligator) as determined by field potential analysis [4,5], which was publicly contested [1,7] until intradendritic recordings were obtained with my colleague, Charles Nicholson, in the early 1970s [3].

The second issue, the calcium dependence of these potentials followed shortly in time after those papers. That Purkinje cell dendrites supported calcium-dependent action potentials was originally demonstrated in avian Purkinje cells [2] at a

\footnotetext{
R. R. Llinás $(\bowtie)$

Department of Physiology and Neuroscience, School of Medicine, New York University,

550 1st Avenue,

New York, NY 10016-6402, USA

e-mail: Rodolfo.Llinas@nyumc.org
}

time when action potentials in vertebrate central neurons were simply not considered, even as a remote possibility.

This issue, we thought, was laid to rest with the papers published with my colleague and friend Mutsuyuki Sugimori. The paper reprinted in this Cerebellar Classics demonstrated both the actual localization of calcium action potentials as well as their non-continuous conduction along the extensive Purkinje cell dendritic tree. This has now been securely established over the last 30 years. But even in this case, papers questioning these findings were published as late as the early 1990s [6].

\section{References}

1. Calvin WH, Hellerstein D, Llinás R, Nicholson C, Freeman JA, Hillman DE. Dendritic spikes versus cable properties. Science. 1969;163:97-7.

2. Llinás R, Hess R. Tetrodotoxin-resistant dendritic spiles in avian Purkinje cells. Proc Natl Acad Sci. 1976;73:2520-3.

3. Llinás R, Nicholson C. Electorphysiological properties of dentrites and somata in alligator Purkinje cells. J Neurophysiol. 1971;34:532-51.

4. Llinás R, Nicholson C, Freeman JA, Hillman DE. Dendritic spikes and their inhibition in alligator Purkinje cells. Science. 1968;160:1132-5.

5. Llinás R, Nicholson C, Precht W. Preferred centripetal conduction of dendritic spikes in alligator Purkinje cells. Science. 1969;163:184-7.

6. Regehr WG, Konnerth A, Armstrong CM. Sodium action potentials in the dendrites of cerebellar Purkinje cells. Proc Natl Acad Sci. 1992;89:5492-6.

7. Zucker RS. Field potentials generated by dentritic spikes and synaptic potentials. Science. 1969;165:409-13. 